\title{
Pre-implantation genetic study and its importance for fertilization in the prevention of genetic disorders
}

\author{
Tárik Kassem Saidah* Waldermar Naves do Amaral' ${ }^{1}$, Patrícia Gonçalves Evangelista1, \\ Roberta Silva Soares Ferreira Ghiggi², Mohamed kassem Saidah² \\ 1 Universidade Federal de Goiás (UFG), Goiânia, GO, Brazil \\ ¿UniEvangélica, Anápolis, GO, Brazil
}

\begin{abstract}
Objective: This review is to address the pre-implantation genetic study and its importance for fertilization in the prevention of genetic disorders. Methods: Review bibliographic. Results: Pre-implantation Genetic Diagnosis (PGD) is a reproductive option for couples at risk of conceiving a child with a known genetic disorder avoiding having an affected child and consequently discontinuing pregnancy or recurrent miscarriages. Several methods for the biopsy of the embryonic material can be used. Polar corpuscle biopsy is usually performed in countries that do not allow embryonic manipulation. Several methods can be used to perform the genetic study. PCR has been the preferred method of PGD diagnosis for disorders of a single gene. Fluorescent in situ hybridization (FISH) is a method for embryonic chromosome analysis, its utility is limited primarily because only a small number of chromosomes can be identified in each embryo. Final considerations: The technique of Pre-implantation Genetic Diagnosis is a great ally of in vitro fertilization, offering these couples the chance to form a healthy family, but there is still a little dissemination of the method.
\end{abstract}

Keywords: genetic study; pgd; fertiliz.

\section{Introduction}

Assisted fertilization is the most advanced treatment for the infertile couple, presenting implantation rates from 27 to $35 \%$, and may present unexpected events with abortion, repeated failures and embryos with genetic alterations and chromosomal anomaly.

Pre-implantation genetic diagnosis (PGD) is the use of reproductive technologies for the genetic analysis of embryos before transfer and implantation. Such practice allowed the transfer of unaffected embryos, and that way, avoid the pregnancy of compromised fetuses. Another application for genetic testing is in the treatment for infertility. ${ }^{2}$

Several methods for the biopsy of the embryonic material can be used. Polar corpuscle biopsy is usually performed in countries that do not allow embryonic manipulation. Biopsy in the cleavage stage is the most used method, but the main disadvantage is the risk of mosaicism in this period, which may be responsible for the false-positive and false-negative results and interfere with the implantation rates. The biopsy of the blastocyst is performed on day 5, can be removed between 5 to 10 cells, has as advantages lower rates than mosaicism, and does not interfere in implantation rates but presents high costs. ${ }^{3}$

Several methods can be used to perform the genetic study. PCR has been the preferred method of diagnosis in PGD for disorders of a single gene being the most common for cystic fibrosis, spinal muscular atrophy, hemoglobin diseases such as $\beta$-thalassemia, Huntington's disease, fragile $X$ syndrome, myotonic dystrophy and mutations that predisposes to cancer as BRCA14,5 Fluorescent in situ hybridization (FISH) is a method for embryonic chromosome analysis, its utility is limited primarily because only a small number of chromosomes can be identified in each embryo. ${ }^{6}$ Comparative genomic

Financial support: Funded by authors.

Conflicts of interest: The authors declare no conflicts of interest.

Submitted: August 08, 2017.

Accepted: November 21, 2017.

Study carried out at UFG, Goiânia, GO, Brazil.

Copyright Saidah et al. This is an Open Access article distributed under the terms of the Creative Commons Attribution License, which permits unrestricted use, distribution, and reproduction in any medium, provided the original work is properly cited. 
hybridization $(\mathrm{CGH})$ mainly involves the analysis of embryos with aneuploidies. It has the advantage of analyzing all the chromosomes in a single study, besides that, the CGH provides a more detailed image of the whole length of each chromosome, allowing the detection of chromosomal segment imbalance.

Therefore, the purpose of this review is to address the pre-implantation genetic study and its importance for the fertilization in the prevention of genetic disorders.

\section{Pre-implantation Genetic Diagnosis - PGD}

Pre-implantation Genetic Diagnosis (PGD) is a reproductive option for couples at risk of conceiving a child with a known genetic disorder avoiding having an affected child and consequently discontinuing pregnancy or recurrent miscarriages. The other options for these couples are gametes donation, remain childless, gestation without genetic testing (reproductive chance) or adoption. Couples submitted to PGD have already been diagnosed for some genetic disorder because they have a family history, have a child committed by a syndrome or are diagnosed in adulthood.?

PGD is useful in the diagnosis of a variety of genetic disorders that are caused by a single mutation in a gene or chromosomal or structural abnormalities, which can be detected in a single cell. ${ }^{5}$

Chromosomal abnormalities, including numerical errors and structural abnormalities, are common in human embryos, and their incidence increases significantly with advancing maternal age. There is no correlation between maternal age and Turner syndrome and sexual chromosome anomalies (47, XXX, 47, XXXY and 47, XYY).,8

Chromosomal abnormalities are the main causes of spontaneous abortions and implantation failure after transfer of embryos in assisted reproduction cycles. ${ }^{10}$

More than $50 \%$ of spontaneous abortions in the first trimester are due to aneuploidies. The most common aneuploidies are trisomies of chromosomes 16, 21 and 22. Trisomies of other chromosomes are rarely seen in clinical pregnancies because they are highly lethal. Monosomies, except for monosomy X (Turner's syndrome), also are not observed in spontaneous abortions. ${ }^{11}$ The most common single gene disorders detected by PGD are beta thalassemia, cystic fibrosis, myotonic dystrophy, Huntington's disease, fragile X syndrome, Comel-Netherton syndrome, and endocrine diseases (including childhood persistent hyperinsulinemic hypoglycemia, congenital adrenal hyperplasia and endocrine neoplasms). ${ }^{12}$

The pre-implantation genetic diagnosis PGD test consists of the use of reproductive technologies for the genetic analysis of embryos before transfer and implantation. Such practice allowed the transfer of unaffected embryos, and that way, avoid the pregnancy of compromised fetuses. ${ }^{1}$ Early research in PGD dates back to Edwards and Gardner, who in 1968 performed the blastocyst biopsy of a rabbit, and were carried out analyzes of Barr's corpuscle to determine gender. PGD became viable in humans with the first in vitro fertilization in 1978 conducted by Edwards and Steptoe. After 10 years in 1988, Monk and Handyside demonstrated the viability of using PGD to detect a single gene disease using mouse blastomeres. ${ }^{13}$ The first successful application of PGD in humans was by Handyside et. al in 1990, which performed the embryonic sexing through a polymerase chain reaction (PCR) to detect the presence of the $Y$ chromosome sequence to prevent males affected with X-linked adrenoleukodystrophy and mental retardation. Shortly thereafter, successful PGD has been reported to cystic fibrosis and many other monogenic disorders. ${ }^{14}$

The PGD is currently used to reduce transmission of genetic disorders to the offspring, and is proposed for carriers of single gene disorders (dominant and recessive, autosomal or X-linked) and carriers of structural chromosomal abnormalities, including, but not limited to reciprocal and Robertsonian translocations, inversions, deletions and insertions. ${ }^{1}$ Another application for genetic testing is the treatment for infertility. Fertility rates in vitro fertilization goes from $27 \%$ to $35 \%$, depending on the patient group, maternal pathologies and technique used..$^{15}$ The implantation depends on the quality of the embryo, the endometrial receptivity and the interaction between both. The most likely cause of low pregnancy rates observed in women undergoing in vitro fertilization, especially those with advanced maternal age and recurrent miscarriages, is the increased incidence of numerical chromosomal abnormalities (aneuploidy) despite the embryonic microscopy exhibiting normal morphology. ${ }^{16}$

In 1995, two teams in the United States used genetic testing to detect chromosomal abnormalities in polar bodies and in patients undergoing in vitro fertilization (IVF) as one of the additional means of embryo selection. ${ }^{7}$ The technique was performed in patients with advanced maternal age, successive implantation failures and abortion, with parents with normal karyotypes. The technique had several nominations, including PGD for aneuploidy screening PGD-AS or PGS. The PGS is therefore the application of preimplantation genetic testing in infertile or subfertile patients with normal karyotypes parents in order to increase fertilization rates. Although the choice of the best embryos could increase the rates of implantation by transfers, a smaller transfer of embryos could occur, resulting in lower rates of implantation. Controlled studies performed after one decade showed lower rates of pregnancies using genetic evaluation. ${ }^{17-19}$

This way various societies such as the American Society for Reproduction Medicine (ASRM), British Fertility Reproduction BFS, American College of Obstetricians and Gynecologists (ACOG) recommended that there is no evidence for routine 
use of PGS. Recently other studies have demonstrated the use of CGH and biopsy of the blastocyst decreased the false positive results for mosaicism in embryos. Recent studies have shown promising data for PGS. ${ }^{20-23}$

\section{Biopsy of embryos}

Decisions about the optimal time to perform biopsy for pre-implantation genetic testing involve careful consideration of multiple factors, including: At what time of embryonic development is the abnormality identified? Are the genetic changes in the sample indicative of abnormalities in the embryo as a whole? Does the timing of the biopsy in relation to the transfer allow enough time for the analysis? Can biopsy compromise the ability of the embryo to develop normally. ${ }^{23}$

The biopsy of embryos for either PGD or PGS purposes can be done at different stages of embryo development during in vitro fertilization procedures. The technique can be performed by biopsy of the oocyte on the first or second polar corpuscles. On the 3rd day during the embryo cleavage with the presence of 5 to 8 cells realizing the removal of 1 or 2 blastomers. It may be blastocyst stage, which contains about 120 cells, are removed from 5 to 10 trophectoderm cells. ${ }^{12}$

The biopsied genetic material may be extracted in different ways as set forth in the following items.

\section{Biopsy of the polar corpuscle}

This biopsy technique is usually performed in countries where embryo biopsy is considered illegal as Italy, Germany and Austria. ${ }^{24}$ Polar corpuscle biopsy requires access to the perivitelline space through the opening of the zona pellucida that can be performed by mechanical means or through the laser. The first description of this type of biopsy was performed by Verlinsky and was initially performed only on the first polar corpuscle (diagnosis preconception). Subsequently, the procedure was performed on both the first and second polar corpuscles for a more accurate diagnosis. ${ }^{25}$

The materials for biopsy can be removed simultaneously or sequentially, both having advantages and disadvantages. Simultaneous biopsy has the advantage that requires less manipulation, but it may be difficult to distinguish between the first and second polar corpuscles, and such differentiation may be necessary for some diagnoses. The main limitation of the polar body biopsy is that it only allows the identification of maternal genes and chromosomes and there is a high incidence of post-meiotic mitoses that are not detected.,., 12

\section{Biopsy at cleavage stage}

For two decades, the predominant method of embryo biopsy has been the biopsy at cleavage stage where usually one, but sometimes, two blastomers are biopsied from the embryo cleavage stage at day 3 of development. The use of this technique was based on a study by Hardy et al., ${ }^{26}$ the initial method uses Tyrode's acid to pierce the zona pellucida to remove the blastomeres. There has been much debate about the biopsy of one or two blastomers in PGD and PGS procedures. Two blastomers will allow a more accurate diagnosis, but having two cells removed, is more invasive to the embryo and can affect implantation. In the PGS as it aims to increase fertilization rates in IVF only a blastomer is biopsied. ${ }^{7}$ The main disadvantage of blastomer biopsy is the risk of mosaicism, which may be responsible for false-positive and false-negative results. ${ }^{27}$ About $15 \%$ to $80 \%$ of the embryos on the 3rd day show mosaicism and only part of them will remain after the 5th day, the difficulty in this technique is know whether the biopsied cell is a precise representation of the biopsied embryo. Initial studies by Hardy et al., ${ }^{28}$ suggested that biopsy of blastomeres did not inhibit the ability of embryos to advance to the blastocyst stage. These data, however, were based on good quality embryos and probably did not accurately represent the quality spectrum of the embryos seen in a typical IVF cycle. Cohen et al. ${ }^{29}$ however demonstrated that single-cell biopsy in the eight-cell stage showed a 12.5\% implantation decrease, and two-cell biopsy showed a $25 \%$ decrease in implantation. ${ }^{29}$ suggested that biopsy of blastomeres did not inhibit the ability of embryos to advance to the blastocyst stage. These data, however, were based on good quality embryos and probably did not accurately represent the quality spectrum of the embryos seen in a typical IVF cycle. Cohen et al. ${ }^{29}$ however demonstrated that single-cell biopsy in the eight-cell stage showed a 12.5\% implantation decrease, and two-cell biopsy showed a $25 \%$ decrease in implantation.

\section{Biopsy in the blastocyst stage}

The human blastocyst contains about 130 cells distributed between the inner cell mass, and the surrounding trophoblast cells, which will become the membranes of the placenta and the fetus. The clinical use of blastocyst biopsy was initially reported by McArthur et al., ${ }^{30}$ and in recent years there has been an increase in the use of this method. The blastocyst biopsy can be performed using two methods. The first is a hole on the 3rd day and the embryos are left in the culture that way some of the trophectoderm cells have herniated, so that the biopsy is performed on the 5th day. 
The problem with this method is that the internal cell mass cells can suffer herniation instead of trophectoderm. In the second method, the hole is drilled on the morning of the 5th day to ensure the herniation of the trophectoderm cells. The blastocyst will rapidly rebuild by closing the biopsy local where the cells were removed.,31 5 to 10 trophectoderm cells are removed. The recovery of 5 to 10 trophectoderm cells from a blastocyst with 100 or 150 cells corresponds to a lower ratio of cell loss (3.3\% to 10\%) than the removal of one or two blastomers from a total from 6 to 8 cells, which reduces the cell content from $12.5 \%$ to $33 \%$. Scott et al., ${ }^{27}$ demonstrated that blastocyst biopsy did not change implantation rates compared to biopsy at the cleavage stage that some studies reported a decrease in rates by up to $39 \%$. Therefore, as an advantage, we can highlight that the biopsy of trophectoderm presents a larger number of cells to study, a smaller number of mosaicism and does not interfere in implantation rates. As disadvantages the cost is higher, need for vitrification techniques and less time to perform the genetic study. It is likely that more PGD centers will adopt trophectoderm biopsy in the future. The most recent ESHRE dataset indicated that only 2.3\% of the biopsies were performed on day 5 or 6 , compared with $79.8 \%$ in the cleavage phase on day $3 .{ }^{32}$

\section{Diagnosis}

\section{Genetic disorders}

PCR has been the favorie method of diagnosis in PGD for disorders of a single gene. Several diagnostic protocols for more than 200 different disorders of a single gene have been reported, being the most common for cystic fibrosis, spinal muscular atrophy, hemoglobin diseases such as $\beta$-thalassemia, Huntington's disease, fragile X syndrome, myotonic dystrophy and mutations that predispose to Cancer as BRCA1. Unlike DNA analysis from blood or amniocentesis, PGD samples usually start from very limited amounts of DNA found in biopsies of blastomers or trophectoderm. Individual cells contain approximately six picograms of DNA, and for many PCR assays, 250 nanograms of DNA are needed as a starting material. This implies that an amplification of about 40,000 times of DNA concentration is required. This number of cycles for amplification of the genetic material may imply DNA errors. ${ }^{24}$ One of the errors is the lost allelle, Allele Dropout (ADO). ADO can be defined as the inability of amplification that affects a heterozygous sample. The Extreme Incidence can reach $20 \%$, leading to various diagnostic errors. ${ }^{12,33}$

\section{PGD for aneuploidies}

This form of PGD, which did not involve tests for genetic diseases and was designed to improve the outcome of in vitro fertilization, was called pre-implantation genetic screening (PGS). The term was first used in Europe, apparently to differentiate it from the analysis of a single gene. ${ }^{7}$

\section{Fluorescent In Situ Hybridization (FISH)}

It is a method for embryonic chromosomal analysis, that uses DNA probes labeled with different stains that binded to their complementary sequence and which can be viewed under a fluorescent microscope. The first chromosome analysis for PGD that used FISH to identify the $X$ and $Y$ chromosomes. This method was quickly used to detect inherited chromosomal abnormalities such as translocations. ${ }^{34}$

Although the FISH method has been applied extensively throughout the world to identify chromosomal abnormalities in embryos, its usefulness is limited primarily because only a small number of chromosomes can be identified in each embryo. This restriction is imposed by the limited number of distinct fluorochromes that are available to label the DNA probes. This can be partially overcome by using the dialing technique but proportional this can not delineate overlapping signals that are labeled with the same fluorochrome. Overlapping signals of different fluorochromes can be distinguished using computerized imaging systems that allow individual color planes to be analyzed independently, but overlapping signals of the same color can not be differentiated and can lead to diagnostic errors. One common approach is to use FISH for five or six chromosomes simultaneously and then, once these results have been analyzed to wash off the signals and re-probe the nucleus for more two, three or four chromosomes. Most laboratories look for $X, Y, 13,16,18,21$ and 22 chromosomes because these are the most common changes in aneuploidies observed in spontaneous abortions. Recently the evidence shows that aneuploidies of other chromosomes are also relatively common in embryos and so a choice must be made on which chromosomes to analyze when using FISH. 6,9

\section{Comparative Genomic Hybridization (CGH)}

The PGD use mainly involves the analysis of embryos with aneuploidies, which are manifested either by an error of segregation in the oocyte meiosis or, less common, in mitotic abnormalities of the embryo, that stand in mosaicism. Embryo aneuploidy usually results in inadequate development, failure of implantation and consequently miscarriage. ${ }^{5}$ 
The most effective approach for complete single-cell karyotyping, to date is CGH (comparative genomic hybridization). This method was originally developed by oncological biologists who had the need to evaluate aneuploidy in a small number of cells from solid tumors. ${ }^{10,11}$

Aneuploidy is extremely related to maternal age and chromosome analysis of abortion products by aCGH shows that it is responsible for $70 \%$ of spontaneous abortions in the first trimester. ${ }^{5}$

CGH works by comparing one DNA sample with another DNA sample known as normal or reference. The DNA test and the reference DNA are labeled with a green and red fluorochrome respectively and then applied simultaneously to a microscope slide that is covered with normal human male chromosomes that are in metaphysis. The sample is hybridized for 2 to 3 days and then analyzed by a computerized system. Both DNAs are hybridized equally to both metaphase chromosomes (McGH) and to specific chromosomal DNA strands (aCGH). The aCGH attaches the DNA strands directly to the slide of the microscope, which takes the analysis time to one day and consequently enables a transfer of the fresh embryo. The intensity of the fluorescence is measured, and if equally colored, we have the presence of yellow color. The red and green color are seen if there is an excess of test DNA or control DNA.5,10,11,35

Recent studies using McGH in all non-transferred embryo bastomers show that only $25 \%$ of the embryos analyzed on the third day were euploid and that more than two-thirds demonstrated mosaicism. Half of these embryos had no normal cells, and $25 \%$ diploid and aneuploid mosaicism. Therefore, the validity of the analysis was questioned on the third day, in relation to the embryo development potential. ${ }^{5}$

The aCGH determines whether there is any quantitative deviation (excess or loss of DNA sequences) present in the test DNA. Therefore, it is able to detect the number of chromosomal copies and chromosome translocations. It is important to emphasize that this method is not able to demonstrate the chromosomal rearrangements. ${ }^{13}$

The advantage of the CGH method over the FISH method is that the entire chromosomal chain can be determined. In addition, the CGH provides a more detailed image of the entire length of each chromosome, allowing the detection of chromosomal segment imbalance. ${ }^{11}$

The first success of the application of CGH in PGD was with a 38 year old patient with a history of infertility and successive failures of IVF, which presented normal embryos by the FISH method. This woman was included in a group of 20 women who had implantation failure, with some choosing the FISH method for half of their embryos and the CGH for the remaining embryos. ${ }^{6}$ The FISH method failed to diagnose chromosomal changes, making it clear that CGH is better at detecting chromosomal errors, but it does not check for all ploidy errors, it can not distinguish, for example, diploid, triploid and tetraploid cells.,14

Um estudo retrospectivo de 75 ciclos de PGD (Mishael et al. ${ }^{36}$ compared the three techniques, FISH, CGH and PCR, clearly observed that CGH increases the efficiency of genetic analysis and significantly improves gestation rates, but presents as the greater limitation the cost of the procedure per embryo, which is relatively high. ${ }^{15}$

\section{Final considerations}

Genetic diagnosis prior to pre-implantation transfer is an established and consolidated procedure in the medical setting. The average number of couples postponing pregnancy after 35 years has increased in recent years, whether for financial reasons or for professional achievement, in contrast the risk of genetic alterations also increases at this age. This technique allows risky couples to have a normal child and exclude embryos with genetic abnormalities leading to an increase in implantation rates and impacting the reduction of abortions, guaranteeing success, however, usually there are few couples who seek this technique beeing necessary demonstrate the need for greater dissemination of the use of the method.

\section{Referências}

1. DAHDOUH EM, BALAYLA M, AUDIBERT F, WILSON RD, AUDIBERT F, BROCK JA, et al. Sogc technical update: technical update: preimplantation genetic diagnosis and screening. J Obstet Gynaecol Can. 2015;37(5):451-63. PMid:26168107. http://dx.doi. org/10.1016/S1701-2163(15)30261-9.

2. BIAZOTTI MCS, PINTO Jr W, ALBUQUERQUE MCRM, FUJIHARA LS, et al. Diagnóstico genético pré-implantacional na fibrose cística: relato de caso. Einstein. 2015;13(1):110-3. PMid:25993078. http://dx.doi.org/10.1590/S1679-45082015RC2738.

3. SCHOOLCRAFT WB, FRAGOULI E, STEVENS J, MUNNE S, KATZ-JAFFE MG, WELLS D. Clinical application of comprehensive chromosomal screening at the blastocyst stage. Fertil Steril. 2010;94(1):1700-6. PMid:19939370. http://dx.doi.org/10.1016/j.fertnstert.2009.10.015.

4. GOOSSENS V, TRAEGER-SYNODINOS J, COONEN E, RYCKE M, Moutou C, Pehlivan T, et al. Eshire PGD Consortium data collection XI: cycles from January to December 2008 with pregnancy follow-up to October 2009. Hum Reprod. 2012;27(1):1887-911. PMid:22572107. http://dx.doi.org/10.1093/humrep/des106. 
5. YAN L, WEI Y, HUANG J, ZHU X, SHI X, XIA X, et al. Advances in preimplantation genetic diagnosis/screening Laboratory of Reproductive Endocrinology and Assisted Reproduction. Sci China Life Sci. 2014;57(7):665-71. PMid:24907939. http://dx.doi. org/10.1007/s11427-014-4683-5.

6. WILTON L. Preimplantation genetic diagnosis and chromosome analysis of blastomeres using comparative genomic hybridization. Hum Reprod Update. 2005;11(1):33-41. PMid:15569702. http://dx.doi.org/10.1093/humupd/dmh050.

7. HARPER JC, SENGUPTA SB. Preimplantation genetic diagnosis: state of the art 2011. Hum Genet. 2012;131(1):175-86. PMid:21748341. http://dx.doi.org/10.1007/s00439-011-1056-z.

8. HASSOLD T, CHEN J, FUNKHOUSER J, JOOSS T, MANUEL B, MATSUURA J, et al. A cytogenetic study of 1000 spontaneous abortions. Ann Hum Genet. 1980;44(1):151-78. PMid:7316468. http://dx.doi.org/10.1111/j.1469-1809.1980.tb00955.x.

9. LEEANDA W. A preimplantation genetic diagnosis pioneer takes a look back. Research Use Only. 2015;1(1):1-4.

10. VANNESTE E, VOET T, CAIGNEC CL, AMPE M, Konings P, Melotte C, et al. Chromosome instability is common in human cleavagestage embryos. Nat Med. 2009;15(5):577-83. PMid:19396175. http://dx.doi.org/10.1038/nm.1924.

11. STEPHENSON MD, AWARTANI KA, ROBINSON WP. Cytogenetic analysis of miscarriages from couples with recurrent miscarriage: a case-control study. Hum Reprod. 2002;17(1):446-51. PMid:11821293. http://dx.doi.org/10.1093/humrep/17.2.446.

12. STERN HJ. Preimplantation genetic diagnosis: prenatal testing for embryos finally achieving its potential. J Clin Med. 2014;3(1):280309. PMid:26237262. http://dx.doi.org/10.3390/jcm3010280.

13. MONK MH, HANDYSIDE AH. Sexing of preimplantation embryos by measurement of X-linked gene dosage in a single blastomere. J Reprod Fertil. 1988;82(1):365-8. PMid:3339593. http://dx.doi.org/10.1530/jrf.0.0820365.

14. HANDYSIDE AH, LESKO JG, TARIN J, WINSTON RM, HUGHES MR. Birth of a normal girl after in vitro fertilization and preimplantation diagnostic testing for cystic fibrosis. N Engl J Med. 1992;327(1):905-9. PMid:1381054. http://dx.doi.org/10.1056/NEJM199209243271301.

15. IKUMA S, SATO T, SUGIURA-OGASAWARA M, NAGAYOSHI M, Tanaka A, Takeda S, et al. Preimplantation Genetic diagnosis and natural conception: a comparison of live birth rates in patients with recurrent pregnancy loss associated with translocation. Plos One. 1-12. http://dx.doi.org/10.1371/journal.pone.0129958.

16. BRAGA DPAF, BORGES JRE. Técnica de alta complexidade: ICSI. In: Dizik A, Pereira DHM, DHM, Cavagna DHM, Amaral WN, organizadores. Tratado de reprodução humana. 3. ed. São Paulo: Segmento Farma; 2014. XX-XX.

17. STAESSEN C, PLATTEAU P, VAN ASSCHE E, Michiels A, Tournaye H, Camus M, et al. Comparison of blastocyst transfer with or without preimplantation genetic screening (PGS)? Experience with blastocyst biopsy and testing for aneuploidy. Hum Reprod. 2004;23(1):1476-8.

18. MASTENBROEK S, TWISK M, ECHTEN-ARENDS JV, SIKKEMA-RADDATZ B, Korevaar JC, Verhoeve HR, et al. In vitro fertilization with preimplantation genetic screening. N Engl J Med. 2007;357(1):9-17. PMid:17611204. http://dx.doi.org/10.1056/NEJMoa067744.

19. MASTENBROEK S, TWISK M, VEEN VDF, REPPING S. Preimplantation genetic screening: a systematic review and meta-analysis of RCTs. Hum Reprod Update. 2011;17(1):454-66. PMid:21531751. http://dx.doi.org/10.1093/humupd/dmr003.

20. YANG Z, LIU J, COLLINS GS, SALEM SA, LIU X, LYLE SS, et al. Selection of single blastocysts for fresh transfer via standard morphology assessment alone and with array CGH for good prognosis IVF patients: results from a randomized pilot study. Mol Cytogenet. 2012;5(1):24. PMid:22551456. http://dx.doi.org/10.1186/1755-8166-5-24.

21. FORMAN EJ, HONG KH, FERRY KM, TAO X, TAYLOR D, LEVY B, et al. In vitro fertilization with single euploid blastocyst transfer: a randomized controlled trial. Fertil Steril. 2013;100(1):110-7. PMid:23548942. http://dx.doi.org/10.1016/j.fertnstert.2013.02.056.

22. SCOTT JR RT, UPHAM KM, FORMAN EJ, HONG KH, Scott KL, Taylor D, et al. Blastocyst biopsy with comprehensive chromosome screening and fresh embryo transfer significantly increases in vitro fertilization implantation and delivery rates: a randomized controlled trial. Fertil Steril. 2013;100(1):697-703. PMid:23731996. http://dx.doi.org/10.1016/j.fertnstert.2013.04.035.

23. SCOTT JR RT, UPHAM KM, FORMAN EJ, ZHAO T, Treff NR. Cleavage-stage biopsy significantly impairs human embryonic implantation potential while blastocyst biopsy does not: a randomized and paired clinical trial. Fertil Steril. 2013;100(1):624-30. PMid:23773313. http://dx.doi.org/10.1016/j.fertnstert.2013.04.039.

24. MONTAG M, KÖSTER M, STROWITZKI T, TOTH B. Polar body biopsy. Fertil Steril. 2013;100(1):603-7. PMid:23796365. http://dx.doi. org/10.1016/j.fertnstert.2013.05.053.

25. VERLINSKY Y, CIESLAK J, IVAKHNENKO V, EVSIKOV S, WOLF G, WHITE M, et al. Preimplantation diagnosis of common aneuploidies by the first- and second-polar body FISH analysis. J Assist Reprod Genet. 1998;15(5):285-9. PMid:9604761. http://dx.doi. org/10.1023/A:1022592427128.

26. HARDY K, MARTIN KL, LEESE HJ, WINSTON RM, HANDYSIDE AH. Human preimplantation development in vitro is not adversely affected by biopsy at the 8-cell stage. Hum Reprod. 1990;5(6):708-814. PMid:2254404. http://dx.doi.org/10.1093/oxfordjournals. humrep.a137173.

27. SCOTT KL, HONG KH, SCOTT JR RT. Selecting the optimal time to perform biopsy for preimplantation genetic testing. Fertil Steril. 2013;100(3):608-14.

28. HARDY K, HANDYSIDE AH, WINSTON RM. The human blastocyst: Cell number, death and allocation during late preimplantation development in vitro. Development. 1989;107(1):597-604. PMid:2612378.

29. COHEN J, WELLS D, MUNNE S. Removal of 2 cells from cleavage stage embryos is likely to reduce the efficacy of chromosomal tests that are used to enhance implantation rates. Fertil Steril. 2007;87(87):496-503. PMid:17141767. http://dx.doi.org/10.1016/j. fertnstert.2006.07.1516. 
30. MCARTHUR SJ, LEIGH D, MARSHALL JT, BOER KA, Jansen RP. Pregnancies and live birthsafter trophectoderm biopsy and preimplantation genetic testing of human blastocysts. Fertil Steril. 2005;84(1):1628-36. PMid:16359956. http://dx.doi.org/10.1016/j. fertnstert.2005.05.063.

31. KOKKALI G, VRETTOU C, TRAEGER-SYNODINOS J, JONES GM, CRAM DS, STAVROU D, et al. Bird of a healthy infant following trophectoderm biopsy from blastocytes for PGD of beta-thalassaemia major. Hum Reprod. 2005;20(1):1855-9. PMid:15878929. http://dx.doi.org/10.1093/humrep/deh893.

32. GOOSSENS V, HARTON G, MOUTOU C, TRAEGER-SYNODINOS J, VAN RIJ M, HARPER JC. Eshre PGD Consortium data collection IX: cycles from January to December 2006 with pregnancy follow-up to October 2007. Hum Reprod. 2009;24(8):1786-810. https:// doi.org/10.1093/humrep/dep059.

33. WELLS D, SHERLOCK JK. Strategies for preimplantation genetic diagnosis of single gene disorders by DNA amplification. Prenat Diagn. 1998;18(1):1389-401. PMid:9949439. http://dx.doi.org/10.1002/(SICI)1097-0223(199812)18:13<1389::AID-PD498>3.0.CO;2-6.

34. MUNNE S, ESCUDERO T, COLLS P, XUEZHONG Z, OTER M, GARRISI M, et al. Predictability of preimplantation geneticdiagnosis of aneuploidy and translocations on prospective attempts. Reprod Biomed Online. 2004;9(6):645-51. PMid:15670413. http://dx.doi. org/10.1016/S1472-6483(10)61775-0.

35. STEPTOE PC, EDWARDS RG. Birth after the reimplantation of a human embryo. Lancet. 1978;12(2):366. PMid:79723. http://dx.doi. org/10.1016/S0140-6736(78)92957-4.

36. MISHAEL T, ELDAR-GEVA T, ZELIGSON S, BEERI R, Zeevi DA, Renbaum P et al. Array-Comparative-Genomic-Hybridization (Acgh) based Preimplantation- Genetic-Diagnosis (PGD) for Balanced Translocation Carriers Improves both Diagnostic and Pregnancy Rates Compared to Fluorescent-In-Situ- Hybridization (FISH) and Polymerase-Chain-Reaction (PCR) based PGD. JFIV Reprod Med Genet. 2015;3(2):1-7.

\section{*Correspondence}

Tárik Kassem Saidah

R. 138, 96 - St. Marista

CEP 74170-140, Goiânia, GO, Brazil

Tel.: +55 (62) 3281-8080

E-mail: tsaidah@hotmail.com

\section{Authors information}

WNA - Doctor Adjunct Professor; Federal University of Goiás. PGE - MSc in Health Sciences; Federal University of Goiás. RSSFG - Doctor. MKS - Doctor.

\section{Authors contribution}

WNA - Review and guidance. TKS - Search Revision and writing. PGE - Review and writing. RSSFG and MKS- Search and Review. 